\title{
Synchronous And Asynchronous Learning In Grammar Classes: Tertiary Level EFL Students' Attitude
}

\author{
Agung Ginanjar Anjaniputra ${ }^{2}$, Dwi Rukmini ${ }^{2}$ \\ \{anjaniputragi@mail.unnes.ac.id ${ }^{1}{ }^{1}$ wiwidwirukmini@mail.unnes.ac.id ${ }^{2}$ \} \\ English Department, Universitas Negeri Semarang, Semarang, Indonesia ${ }^{1,2}$
}

\begin{abstract}
Implementing online learning becomes inevitable due to the Government's policyin responding to the Covid-19 pandemic. Educational institutions all over the country in primary, secondary, and tertiary levels urge teachers to teach from home. While online learning is mandatory during this pandemic, its implementation in the fields is more varied and heterogenous among practitioners. In addition to it, from the perspective of students, online learning for more than half of a semester is new and results in challenges for them. Besides, to learn grammar is still deemed difficult by most EFL learners. Not only do students have to adapt to innovative ways of learning grammar, but they are also required to learn a terrifying ordeal of taking the subject. Hence, this study is intended to examine students' attitude towards synchronous and asynchronous learning of grammar. To collect the data of their attitude, a survey design was administered to 7 classes by adapting Tang \& Chaw's (2013) questionnaire. The results show that the students' attitude towards asynchronous and synchronous learning can be seen from six aspects comprising learning flexibility, technology use, learning readiness, study management, online interaction, and online practices. To conclude, synchronous and asynchronous learning can be implemented with respect to students' inclination and the nature of courses being learnt.
\end{abstract}

Keywords: blended learning, EFL learning, synchronous, asynchronous, grammar, tertiary level

\section{Introduction}

The covid-19 pandemic has brought about significant changes in everyday life. People are instructed by the government to stay at home. Implementing online learning has become inevitable due to the Government of Indonesia's policy on working from home (Indonesia's Ministry of Education and Culture, 2020). Educational institutions all over the country in primary, secondary, and tertiary levels urge teachers to teach from home. However, debates over what is best to be implemented are prevalent among practitioners. Some propose synchronous learning because it allows teachers to directly deliver the materials, whereas some others have a predilection for asynchronous learning for it provides a wide range of activities. Hence, a study concerning students' attitude is expected to address such an issue so as to understand students' view on 
synchronous and asynchronous learning, which in turn allows for improving strategies to be successful in teaching grammar.

From the perspective of students, online learning for more than half of a semester is new and results in challenges for them. We frequently heard that students are having difficult time learning online (see Anugrahana, 2020; Layali \& Al-Shlowiy, 2020; Nartaningrum \& Nugroho, 2020). They strive harder and put a lot of effort for online classes than they do for traditional classes. Not only are they required to own a stable internet connection, but they also necessitate time management, autonomy, motivation and resilience to the new trends of learning, in the EFL context in particular.

By most EFL learners, to learn grammar is still deemed difficult. Not only do students have to adapt to innovative ways of learning grammar, but they are also required to learn a terrifying ordeal of taking the subject. Therefore, knowing the online modes of learning grammar that the students are comfortable with is worth investigating as students can learn better if they enjoy the learning.

Most studies vis-à-vis online or blended learning in EFL learning have been limited to hybrid learning in general or one of the modes, synchronous or asynchronous. Among others are Cunningham, Fägersten, and Holmsten (2010) and Kozar (2012) that investigate synchronous tools in English language teaching. The former yields that learning English synchronously may cause problems for students (Cuninngham et al., 2010). In the meantime, the latter suggests slow development and employment of synchronous English learning in Rusia (Kozar, 2012). However, how students react to this mode of learning needs refinement as technology nowadays has advanced greatly, compared to eight to ten years ago. The challenges that existed cannot be similar to the current state.

In addition, studies regarding students' attitude and perception toward online learning have before been conducted, encompassing perceptions of students on synchronous lessons (Altiner, 2015), attitude towards blended learning (Tang \& Chaw, 2013; Akbarov, Gönen, \& Aydoğan, 2018; Karaaslan \& Kılıç, 2019) and mobile learning (AlEmran, Elsherif, \& Shaalan, 2016), and both perceptions and attitude towards asynchronous lessons (Pinto-Llorente, Sanchez-Gomez, García-Penalvo, CasillasMartín, 2016). Nevertheless, a study concerning both synchronous and asynchronous learning is underrepresented.

One study on synchronous and asynchronous learning was once conducted by Khodaparast \& Ghafournia (2015). The results revealed that these modes impacted on vocabulary learning, leaving a gap for us to examine synchronous and asynchronous learning of grammar from the students' viewpoint. As for grammar, research in the context of online or distance learning is scarce, and from the side of students, remains unexplored, if not, unknown. Bearing these in mind, the current study seeks to understand how students' attitude toward synchronous and asynchronous learning is.

\section{Methodology}


The data were collected by using a survey design which was administered online to 7 classes. The classes were chosen as the groups of the students have experienced online grammar instructions both through synchronous learning via live video conferences and asynchronous learning by means of the provision of materials, discussion, quizzes and assignments in Learning Management System (LMS).

By adapting Tang \& Chaw's (2013) questionnaire, there are seven aspects of attitude: learning flexibility, online learning, study management, technology use, classroom learning, online interaction, and the learning readiness. However, only six components were developed into the questionnaire. The aspect of Classroom Learning was left out since this study only focused on two modes of online learning, synchronous and asynchronous ones.

The adaptation covered the deletion of the classroom learning aspect and the specification of the study management, online learning, and online interaction aspects into synchronous and asynchronous learning. Thus, 9 aspects in the questionnaire encompass Learning Flexibility, Technology Use, Online Learning Readiness, Synchronous and Asynchronous Online Interaction, Synchronous and Asynchronous Study Management, and Synchronous and Asynchronous Learning Practice. These constructs were used to depict students' attitude toward the synchronous and asynchronous learning in grammar classes.

The questionnaire was a 4-points Likert Scale consisting of 50 items. For each item, the respondents answered Strongly Agree, Agree, Disagree, and Strongly Disagree. The questionnaire was created on Google Form and, for its validity to gain insight of the students' attitude toward grammar learning, the information about the intention was put at the beginning of the questionnaire. From administering the questionnaire, 101 responses were collected, 11 of which were incomplete responses, thus including only 90 responses analyzed descriptively.

A descriptive qualitative analysis was used to report the data. The items of the questionnaire were first sorted based upon the aspects. The aspects were then coded; LF stands for Learning Flexibility, TU for Technology Use, LR for Online Learning Readiness, SM for Synchronous Study Management, AM for Asynchronous Study Management, SI for Online Synchronous Interaction, AI for Online Asynchronous Learning, SP for Synchronous Learning Practice and AP for Asynchronous Learning Practice. Each item was then calculated to indicate scores derived from a scale ranging 1-4 for positive statements and 4-1 for negative statements. The results were interpreted and discussed accordingly.

\section{Finding and Discussion}

\subsection{Students' attitude toward online learning and related constructs}


By analyzing 90 responses of the students, each construct is presented in percentage and the overall score. The overall percentage of the students' attitude towards online learning revealed that $20,45 \%$ strongly agreed, $46,83 \%$ agreed, $27,62 \%$ disagreed, and $5,10 \%$ strongly disagreed. The overall result indicated that more than two third of the students have positive attitude. In the meantime, the detailed percentage and scores of each construct are shown in the tables below.

Table 1. Percentage and score of each construct

\begin{tabular}{llllll}
\hline & \multicolumn{2}{l}{ Percentage (\%) } & Mean \\
\cline { 2 - 5 } & SA & A & D & SD & Score \\
\hline LF & 46,11 & 45,56 & 7,22 & 1,11 & 3,078 \\
TU & 47,22 & 46,94 & 5,28 & 0,56 & 3,408 \\
LR & 13,70 & 58,89 & 25,56 & 1,85 & 2,844 \\
SM & 16,85 & 48,15 & 27,41 & 7,59 & 2,742 \\
AM & 10,56 & 48,52 & 31,30 & 9,63 & 2,6 \\
SI & 13,33 & 43,17 & 37,30 & 6,19 & 2,637 \\
AI & 11,43 & 49,68 & 31,75 & 7,14 & 2,654 \\
SP & 13,15 & 40,74 & 39,26 & 6,85 & 2,602 \\
AP & 11,67 & 39,81 & 43,52 & 5,00 & 2,581 \\
\hline
\end{tabular}

Table 2. Means and standard deviations of the questionnaire for all participants

\begin{tabular}{lllll}
\hline & $\mathrm{T}^{*}$ & $\mathrm{M}$ & $\mathrm{S}$ & $\%$ \\
\hline LF & 20 & 15,39 & 2,08 & 76,95 \\
TU & 16 & 13,63 & 1,82 & 85,19 \\
LR & 12 & 8,53 & 1,79 & 71,08 \\
SM & 24 & 16,46 & 2,88 & 68,58 \\
AM & 24 & 15,6 & 2,74 & 65 \\
SI & 28 & 18,46 & 3.22 & 65,92 \\
AI & 28 & 18,58 & 2,82 & 66,36 \\
SP & 24 & 15,62 & 2,71 & 65,08 \\
AP & 24 & 15,49 & 2,15 & 64,54 \\
$\Sigma$ & 200 & 137,76 & 22,21 & 68,88 \\
\hline
\end{tabular}

*T is the possible highest mean (in LF construct, 4 as the highest point on the scale multiplied by 5 , the number of items in this construct).

Table 2 shows a comparison of the percentage of each construct. The number of items in each construct was first multiplied by the highest point possible, 4 . Then, the mean was divided by the total score of the construct $(\mathrm{T})$. Thus, the percentage is revealed that TU received the highest score $(85,19 \%)$, followed by LF $(76,95 \%)$ and LR $(71,08 \%)$. Meanwhile, asynchronous learning practice and asynchronous learning management obtained the lowest ratings, consecutively $64,54 \%$ and $65 \%$. This, to some extent, denotes an interesting finding that albeit students' positive attitude toward technology 
used in the classrooms, the students seemingly had a hard time to manage and attend asynchronous learning. This might be due to the students not being accustomed to this new approach of learning.

It is also worthy of note that flexibility of learning experienced mostly in asynchronous learning, as students can learn at their best in terms of time and space, does not correspond to their study management. This indicates that personalized learning can hardly be achieved by the students. The problematic personalization of learning may be experienced by learners, and also affect their inclination not to attend asynchronous classes which highly demands autonomous and persistent learners.

To look over the other matters in detail, each construct is conveyed in the following paragraphs. The results are going to be presented from general constructs associated with online learning (LF, TU, LR) to specific constructs of synchronous and asynchronous learning including study management, interaction, and practice.

The students' ratings on LF is related willingness to access and study the materials whenever and wherever they want to as online grammar learning is more flexible for them.

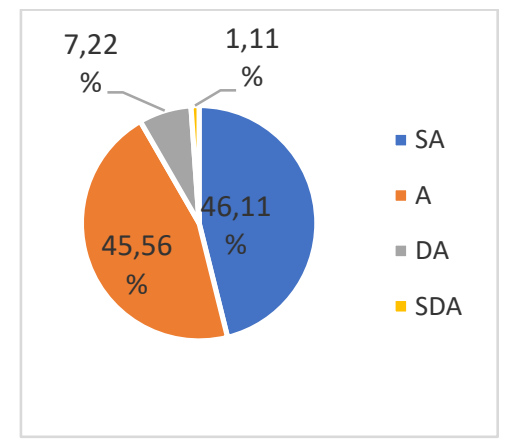

Fig 1. Percentage of students' responses to Learning Flexibility

Of 5 items about decision of where and when to study and studying at their own pace, this construct received relatively high percentage $(76,95 \%)$. The figure shows that the learners' attitude toward the learning flexibility is high since more than $90 \%$ of students, SA and A combined, agreed that they demanded learning flexibility. Learners tend to prefer a flexible study time, place, and materials provided. Nevertheless, one striking finding is that the students had an inclination to have their grammar learning schedule set by the institution. The item "I want my study scheduled by the institution" received $23,33 \%$ of the students who strongly agreed and $62,22 \%$ of them who agreed to it.

In addition to LF, Technology use (TU) in online grammar classes received positive attitude from the students. The construct entails the items "I believe technology is useful for learning", "I am familiar with the use of technology in the classrooms", "I think 
technology is easy to use in learning", and "I think technology should be used in learning". Figure 2 sums up the ratings from the students.

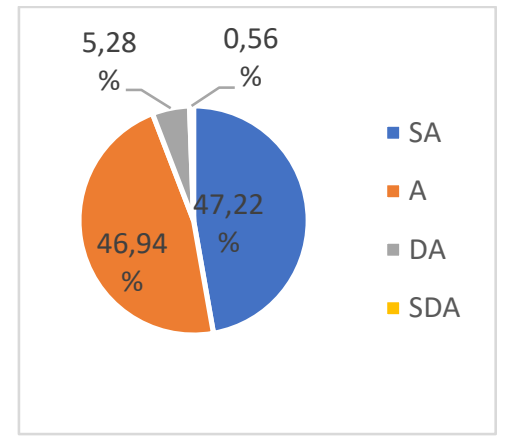

Fig 2. Percentage of students' responses to Technology Use

According to the graphic, $47,22 \%$ of the students strongly agreed and $46,94 \%$ of them agreed to the ideas of implementing technology in the classrooms, particularly in grammar classes. The one item in the construct that received the highest rating is about their belief that technology is useful, scoring 3,74 out of $4(93,5 \%)$. In line with the previous finding on LF, this finding also denotes the students' positive attitude toward online learning, the two approaches of which, synchronous and asynchronous, require technology use. With such a good attitude, it is expected that the learning of grammar with the aid of technology would not be buerdensome for the students.

Regarding LR, Tables 1 and 2 has indicated that this construct received ratings of 2,844 out of $4(71,08 \%)$. The construct concerns the students' readiness to register, join, and attend online grammar classes or courses. Compared to the previous two constructs, LR has relatively lower ratings. The percentage of the three items combined is illustrated below.

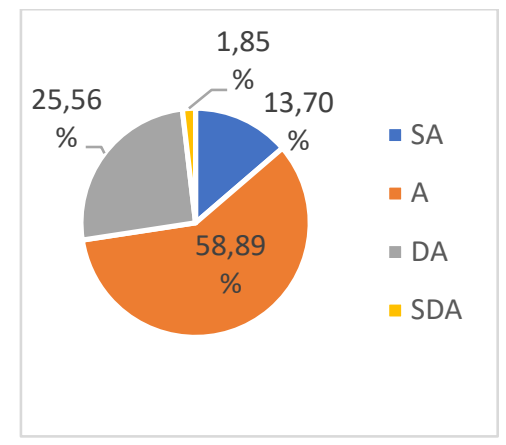

Fig 3. Percentage of students' responses to Online Learning Readiness 
As illustrated in Figure 3, the students' readiness towards the online grammar learning is not really convincing. Only $13,70 \%$ of the students strongly agreed, and $58,89 \%$ agreed. In this regard there are still a relatively high number of students who disagreed $(25,56 \%)$ and strongly disagreed $(1,85)$. Despite the results, this construct, as shown in Table 2, has the lowest point of Standard Deviation $(1,79)$. This implies that the attitude of the students does not vary too much, given most of them seemed to be ready to attend online grammar classes both synchronously $(2,77)$ and asynchronously $(2,91)$.

This finding needs to be examined more closely. The students who strongly disagreed and disagreed seemingly prefer to study face to face than online. Due to the pandemic, they are struggling to study online so as to adapt to synchronous and asynchronous learning through website, LMS, Zoom meeting platform, etc. Which is more prevalent is how they adapt to the new modes of grammar learning that is deemed difficult.

General aspects of attitude toward online learning in grammar classes have been conveyed. What is more is to go over the specific aspects of synchronous and asynchronous learning. Initially, the aspect of study management is examined. It consists of six items related to the learners' activity including doing the assignment, organize the time, motivation, and responsibility in online learning. The following is how students responded to the SM aspect.

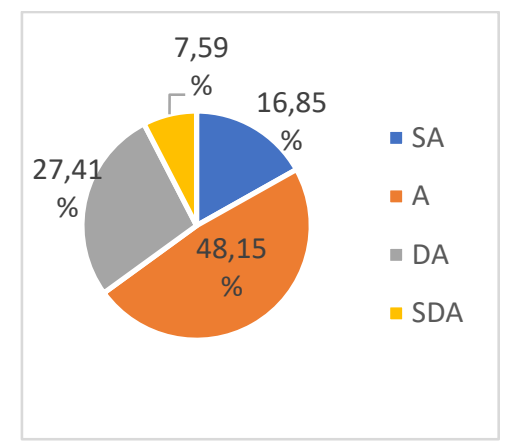

Fig 4. Percentage of students' responses to Synchronous Learning Management

Figure 4 illustrates that in all the six items, $48,15 \%$ of the students agreed that they can manage their study in grammar classes taught synchronously. While, it is only $16,85 \%$ of them strongly agreed to it. Even, this percentage is lower than $27,41 \%$ of the students who disagreed. Overall, the positive attitude of the students toward this construct is $68,58 \%$ (see Table 2).

In order to see how the students responded to AM, Figure 5 illustrate the results. 


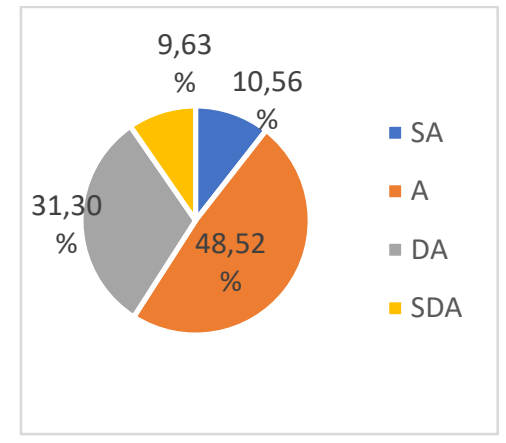

Fig 5. Percentage of students' responses to Asynchronous Learning Management

In the figure above, likewise SM, AM also receives the highest percentage of 48,52\% that the students agreed. Yet, the percentage of the students who disagreed to AM $(31,30 \%)$ is higher than that in SM. This percentage is almost three times of the student percentage that strongly agreed $(10,56 \%)$. Finally, the overall rating of this construct is $65 \%$, which is slightly lower than that of SM. Thus, the students respond more positively to synchronous learning in terms of the overall study management.

The item "I am more likely to miss assignment due dates in live video conferences" received a low rating 1,98 out of 4, and the item "I am more likely to miss assignment due dates in online classes on LMSs" received the lowest rating 1,88 out of 4 . The results on the two items indicate that the students are more unlikely to miss assignments when they are learning asynchronously. It seems that asynchronous online learning motivates and helps learners to manage their time to do assignments.

For online interaction, synchronous and asynchronous learning of grammar also yielded different ratings from the students. SI and AI received the overall rating of $65,92 \%$ and $66,36 \%$ consecutively. AI obtained better responses from the students albeit the possibly unapparent difference. Online interaction is concerned with seven items about the interaction between lecturers and learners, learners and learners, and the communication among them. Figures 6 and 7 illustrate the results of the responses.

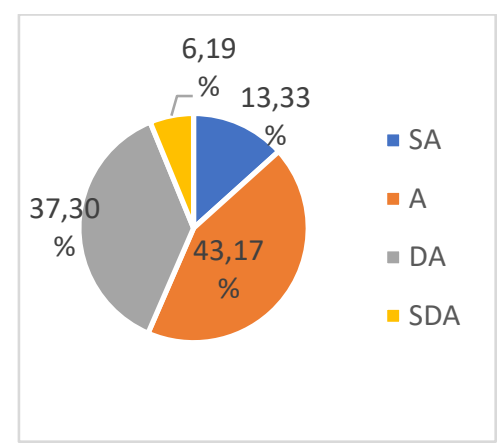


Fig 6. Percentage of students' responses to Online Synchronous Interaction

The figure above shows most of the students (43,17\%) agreed, but more than one third of them $(37,30 \%)$ disagreed. Besides, $13,33 \%$ strongly agreed, yet $6,19 \%$ strongly disagreed. The number, especially one showing disapproval, cannot be taken for granted as this can be an indication of interaction that can rarely be facilitated in online synchronous grammar meetings.

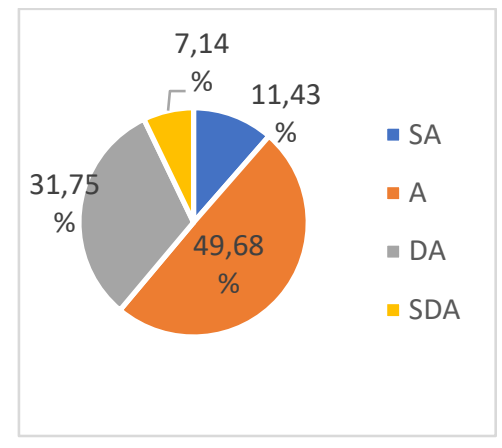

Fig 7. Percentage of students' responses to Online Asynchronous Interaction

Figure 7, on the other hand, depicts ratings from the students as responses to interaction in online asynchronous classes. It is displayed that almost half of the students $(49,68 \%)$ is in agreement with interaction facility of asynchronous classes. In addition to this rating, there are also $31,75 \%$ that disagreed, 11,43 that strongly disagreed, and 7,14 that strongly disagreed. Compared to SI, AI received better ratings, which might be affected by students' inclination of learning flexibility (LF) so that the students can better learn at their own pace. The flexibility of study time and learning pace is not feasible in synchronous learning which is only flexible in terms of space.

The implementation of synchronous and asynchronous learning in grammar classes is also investigated so as to capture the students' attitude thoroughly. The number of items for each is six items that have to do with the effectiveness of implementing online synchronous and asynchronous learning. in general, it should be noticed that SP received the lowest rating from the students $(64,54 \%)$. In the meantime, AP received better ratings of $68,88 \%$. The extent that the students agreed or disagreed to their practice is illustrated in Figures 8 and 9. 


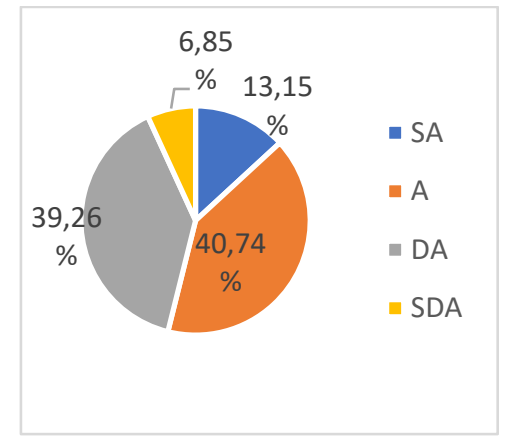

Fig 8. Percentage of students' responses to Synchronous Learning Practice

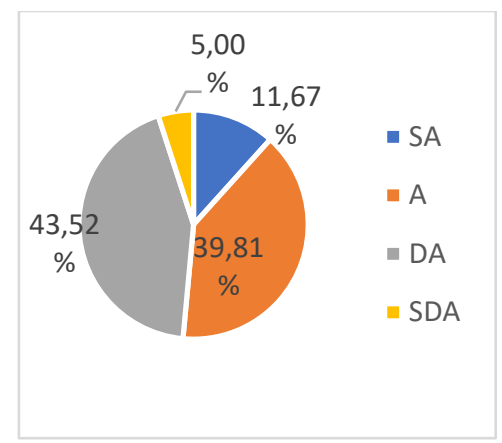

Fig 9. Percentage of students' responses to Asynchronous Learning Practice

Figure 8 displays the percentage of the students that agreed $(40,74 \%)$ is higher than that which disagreed $(39,26 \%)$. Moreover, the students who strongly agreed $(13,15 \%)$ is also higher than those whose strongly disagreed (6,85\%). Meanwhile, Figure 9 shows a tendency that more students disagreed $(43,52 \%)$ than agreed $(39,81 \%)$. Furthermore, there are $11,67 \%$ of the students who strongly agreed and $5 \%$ who strongly disagreed. Therefore, the students showed more disagreement than agreement to AP.

Looking more closely at the two figures, SP and AP share something in common where the percentage of SA is higher than that of SDA. However, A and DA in SP and AP are different in a way that $\mathrm{A}$ is higher than DA in SP, whereas DA is higher than A in AP. Besides, the distinction can also be marked that A and DA in AP leaves more gap $(3,71 \%)$ than those in SP $(1,48 \%)$. This result thus signifies more positive attitude toward synchronous learning, which corresponds to the result shown in Table 2.

As having been presented above, the students had a positive attitude toward online synchronous and asynchronous learning. To be more specific, synchronous learning received slightly more positive attitudes from the students. This might result from their 
previous learning habit with which they are comfortable, which is very normal. In other words, the students are used to grammar learning that allows teachers to explain the materials to them.

The result bears a resemblance to the study conducted by Shahrokni \& Talaeizadeh (2013, in Kosar 2016), it is stated that learners' have a positive attitude towards blended learning. Moreover, Tang and Chaw (2013) added that the support of the internet should also be considered. In this regard, the internet may also be the cause that hinders them to have better attitude toward synchronous online interaction as it necessitates a stable connection of the internet. In conclusion, the success of blended learning is on the learners' awareness and the technology support.

In addition, despite students' preference of learning flexibility in grammar class, they want to learn wherever and whenever they like to, yet when it comes to scheduling, they want it to be fixed beforehand by the institution. For example, teachers can provide students with the materials as scheduled, yet let them study at their own pace at their best time and place. In the meantime, technology use must also be considered in grammar classes. Gamification with the aid of technology can be a choice to teach grammar in this pandemic.

Regarding the flexibility of learning, Atmojo \& Nugroho (2020) argue that asynchronous learning is more flexible that the synchronous learning, but teachers seem to provide too much synchronous learning in relation to the policy of the institution. Therefore, as indicated that the students are more inclined to have flexible learning time in grammar classes, asynchronous learning can be conducted intensely by considering the content, technology use, and the pedagogy of EFL learning.

The students are seemingly ready to study online. Their self-awareness of the online learning is high as they also responded positively to the constructs of Learning Flexibility and Technology Use. They can manage themselves better in synchronous learning and interact with others online asynchronously. They are also ready to learn through their lecturer direction online. However, their readiness should be supported by persistence in learning so as to be able to manage the study very well and successfully because online learning is totally different from traditional, offline learning.

Teachers are suggested that they teach students by taking their needs into consideration. Synchronous and asynchronous modes of learning, particularly in grammar classes, can be utilized. This is in similar vein with a notion that synchronous and asynchronous media certainly address the needs of diverse student styles (Cunningham et. al., 2010).

\section{Conclusions}

The students' attitude toward online synchronous and asynchronous learning are positive. The aspects that received the highest ratings from the students are TU 
(85,19\%), followed by LF (76,95\%) and LR (71,08\%). Meanwhile, the lowest rating was on online asynchronous practice (AP) with $64,54 \%$.

To be more specific, online synchronous learning received slightly more positive attitude than online asynchronous learning. The students can benefit from online synchronous learning especially in terms of the study management (AM) and its practice (AP) as they perceived it to be more effective for them in this current state. Online asynchronous learning got the ratings higher in terms of the interaction which is seemingly plausible as interaction in asynchronous learning requires a lesser amount of the internet bandwidth.

This study has revealed that notwithstanding students' preferences of flexible learning, the flexibility only applies to personal learning time, place, and pace, regardless of the scheduling. In addition, although LF, TU, and LR received high ratings from the students, some aspects of study management, interaction, and the practices of the two modes need improvement so that the students can learn grammar effectively. Gamification of learning might be a choice by implementing both online synchronous and asynchronous in accordance with students' necessity and characteristics.

\section{References}

[1] Akbarov, A., Gönen, K., \& Aydoğan, H. (2018). Students' attitudes toward blended learning in EFL context. Acta Didactica Napocensia, 11(1), pp. 6168. DOI: 10.24193/adn.11.1.5.

[2] Al-Emran, M., Elsherif, H. M, \& Shaalan, K. (2016). Investigating attitudes towards the use of mobile learning in higher education. Computers in Human Behavior, 56(2016), pp. 93-102. http://dx.doi.org/10.1016/j.chb.2015.11.033

[3] Altiner, C. (2015). Perceptions of ndergraduate students about synchronous video conference-based English courses. Procedia - Social and Behavioral 199(2015), pp. $627-633$.

[4] Anugrahana, A. (2020). Hambatan, solusi dan harapan: pembelajaran daring selama masa pandemi covid-19 oleh guru sekolah dasar. Scholaria: Jurnal Pendidikan dan Kebudayaan, 10(3), pp.282-289.

[5] Atmojo, A. E. P, \& Nugroho, A. (2020). EFL Classes Must Go Online! Teaching Activities and Challenges during COVID-19 Pandemic in Indonesia. REGISTER JOURNAL, 13(1), pp. 49-76. DOI: https://doi.org/10.18326/rgt.v13i1.49-76

[6] Cunningham U., Fägersten, K. B., \& Holmsten, E. (2010). “Can you hear me, Hanoi?" Compensatory mechanisms employed in synchronous net-based 
English language learning. International Journal of Research in Open and Distance Learning, 11(1), pp. 161-177.

[7] Karaaslan, H., \& Kılıç, N. (2019). Students' attitudes towards blended language courses: A case study. Journal of Language and Linguistic Studies, 15(1), pp. 174-199. Doi:10.17263/jlls.547699

[8] Khodaparast, F., \& Ghafournia, N. (2015). The effect of Asynchronous/Synchronous Approaches on English. English Language Teaching, 8(4), pp. 117-127. doi: 10.5539/elt.v8n4p117

[9] Kosar, G. (2016). A study of EFL instructors' perceptions of Blended Learning. Procedia - Social and Behavioral Sciences, 232(2016), pp. 736-744.

[10] Kozar, O. (2012). Use of synchronous online tools in private English language teaching in Russia. Distance Education, 33(3), pp. 415-420, DOI: 10.1080/01587919.2012.723164

[11] Layali, K., \& Al-Shlowiy, A. (2020). Students perceptions of e-learning for ESL/EFL in Saudi universities at time of coronavirus: A literature review. Indonesian EFL Journal, 6(2), pp.97-108. Doi: 10.25134/ieflj.v6i2.3378

[12] Indonesia's Ministry of Education and Culture. (2020, March). Surat Edaran Menteri Pendidikan dan Kebudayaan Republik Indonesia tentang Pelaksanaan Kebijakan Pendidikan dalam Masa Darurat Penyebaran Corona Virus Disease (No. 4 2020).

[13] Nartiningrum, N., \& Nugroho, A. (2020). Online Learning amidst Global Pandemic: EFL Students' Challenges, Suggestions, and Needed Materials. ENGLISH FRANCA: Academic Journal of English Language and Education, 4(2), pp. 115-140 DOI: http://dx.doi.org/10.29240/ef.v4i2.1494

[14] Olga Kozar (2012) Use of synchronous online tools in private English language teaching in Russia, Distance Education, 33:3, 415-420. doi: 10.1080/01587919.2012.723164

[15] Pinto-Llorente, A. M., Sanchez-Gomez, M. C., García-Penalvo, F. J., \& Casillas-Martín, S. (2016). Students' perceptions and attitudes towards asynchronous technological tools in blended-learning training to improve grammatical competence in English as a second language. Computers in Human Behavior, (2016), pp. 1-12. Doi: http://dx.doi.org/10.1016/j.chb.2016.05.071

[16] Tang, M. C., \& Chaw, Y. L. (2013). Readiness for blended learning: understanding attitude of university students. International Journal of Cyber Society and Education, 6(2), pp. 79-100 doi: 10.7903/ijcse.1086 